\title{
Short Pulse Cytochalasin B Treatment of Mouse Fibroblasts
}

\author{
Frank P. Cheng' and Richard E. Crang \\ Department of Biological Sciences, Bowling Green State University, \\ Bowling Green, OH 43403, U.S.A.
}

Received June 13, 1977

The drug cytochalasin B (CB), when applied to tissue cultures, was revealed by early studies to have inhibitory effects on various cellular activities (Carter 1967, Copeland 1974, Gail and Boone 1971, Wessells et al. 1971, Zigmond and Hirsch 1972). The possibility that cytochalasins might have direct activity on fibrils of F-actin (Spudich and Lin 1972) was experimentally repudiated by other workers (Forer and Behnke 1972). Upon viewing cytochalasin D (CD) drug effect on tissue culture cells with scanning electron microscopy, knobby protrusions, or socalled zeiotic blebs, were revealed to be a general cell response. The formation of zeiotic blebs, were studied intensively and described as resulting from a herniation of the cell endoplasm through the cell surface at sites of microfilament displacement (Godman et al. 1975, Miranda et al. 1974a, 1974b). Such displacement of microfilaments occurred in the cortex during cell contractions induced by the cytochalasins. This paper reports on the very early effects of CB on fibroblastic tissue culture cells as viewed by scanning electron microscopy and proposes a hypothetical model for the expansion of cell membranes into zeiotic blebs.

Materials and methods

Cells

Monolayer cultures of L-929 cells (mouse fibroblasts) were maintained at $37^{\circ} \mathrm{C}$ in Medium 199 (Grand Island Biological Co., Grand Island, NY.) supplemented with $10 \%$ fetal calf serum, $100 \mu \mathrm{g} / \mathrm{ml}$ streptomycin and $100 \mathrm{U} / \mathrm{ml}$ penicillin $\mathrm{G}$. Subcultures were obtained after washing with phosphate buffered saline (PBS) and by trypsinization. Cells for microscopic examination were grown in the same medium as above on $9 \times 22 \mathrm{~mm}$ glass coverslips in Leighton tubes. Only those cells which were grown in the tubes for $48 \mathrm{~h}$ were used for experiments.

\section{Cytochalasin B treatment}

Cytochalasin B (Aldrich Chem. Co., Milwaukee, WI) stock solutions were prepared in dimethysulfoxide to $1 \mathrm{mg} / \mathrm{ml}$ and then added to the culture media giving a $10 \mu \mathrm{g} / \mathrm{ml}$ concentration. Treatment of the cells involved pipetting the standard growth medium from selected cultures and adding the CB-supplemented medium for selected times. Cells were treated for $20 \mathrm{sec}$ and for 1, 5, 10, 30, and

1 Present address: Tissue Culture Laboratory, Beaumont Hospital, Royal Oak, Michigan 48067 U.S.A. 
60 min. Coverslips were removed after CB treatment and prepared for scanning electron microscopy.

\section{Scanning electron microscopy}

Coverslips with attached cells were rinsed twice with prewarmed PBS and fixed in $2 \%$ glutaraldehyde buffered with $0.15 \mathrm{M}$ cacodylate buffer $(\mathrm{pH}=7.3)$ at $21^{\circ} \mathrm{C}$ for $1 \mathrm{~h}$. They were then subsequently washed with the same buffer, osmicated $(1 \%$ $\mathrm{O}_{8} \mathrm{O}_{4}$ in $0.15 \mathrm{M}$ cacodylate buffer for $1 \mathrm{~h}$ ), and dehydrated through an ethanol series. Specimens were dried by critical point method in a Tousimis Samdri PVT unit using $\mathrm{CO}_{2}$ as the transition fluid. The coverslips were then mounted on aluminum stubs and coated with approximately $200 \AA$ gold in a cold sputtering device, Specimens were viewed with an Hitachi HHS-2R scanning electron microscope operating at $20 \mathrm{kV}$.

\section{Results}

Viewed with the SEM, typical log phase L-cell populations were primarily composed of two morphological types: 1) small rounded cells exhibiting numerous microvilli (Fig. 1) and; 2) more typical fibroblastic cells which were spindle or stellate in shape with fewer microvilli per unit surface area (Fig. 2). The blebbed morphology as described by Porter et al. (1973) in Chinese hamster overy (CHO) cells appeared infrequently in log phase cultures, but increased when cells reached higher densities.

Zeiotic blebs appeared after $20 \mathrm{sec}$ of cytochalasin B (CB) treatment in a log phase population. Initially, the blebs were distributed evenly over the cell surface and were more obvious in rounded cells than in spindle shaped and stellate cells. However, the disappearance of microvilli combined with cell surface folding was more pronounced in the latter (Figs. 3 and 4). The zeiotic blebs first appeared as hemispherical bodies (Fig. 4) and then enlarged to form clavated or bulbous ends on erect stalks (Fig. 5). The aggregation of zeiotic blebs near the tips of pseudopodia in spindle shaped and stellate cells occurred with 5 min after CB treatment, along with the virtual disappearance of microvilli in the central cell area (Fig. 6). The subsequent events in spindle and stellate cell development were similar to $\mathrm{CD}$ treatment on different cell lines as described by Godman et al. (1975). Within $10 \mathrm{~min}$ after CB treatment the zeiotic blebs aggregated toward specific sites of cell surfaces to form clusters which persisted as long as the drug was present.

Figs. 1-6. 1, control L-cell-no CB treatment. Cell is rounded with numerous microvilli. $\times 4800$. 2, control. Part of a spindle shaped cell with scattered microvilli. $\times 3000$. $3, \mathrm{CB}$ treatment for $20 \mathrm{sec}$. Zeiotic blebs well established in rounded cells but are not so apparent in spindle shaped cells. $\times 800.4, \mathrm{CB}$ treatment for $20 \mathrm{sec}$. Portion of spindle shaped cell with surface folds, rudiments of microvilli, and a semispherical zeiotic bleb, $\times 8000.5, \mathrm{CB}$ treatment for $20 \mathrm{sec}$. Rounded cell with numerous zeiotic blebs amid many persisting microvilli. $\times 3000$. $6, \mathrm{CB}$ treatment for $5 \mathrm{~min}$. Stellate cell with zeiotic blebs aggregated at marginal sites and virtually lacking microvilli. $\times 2400$. 


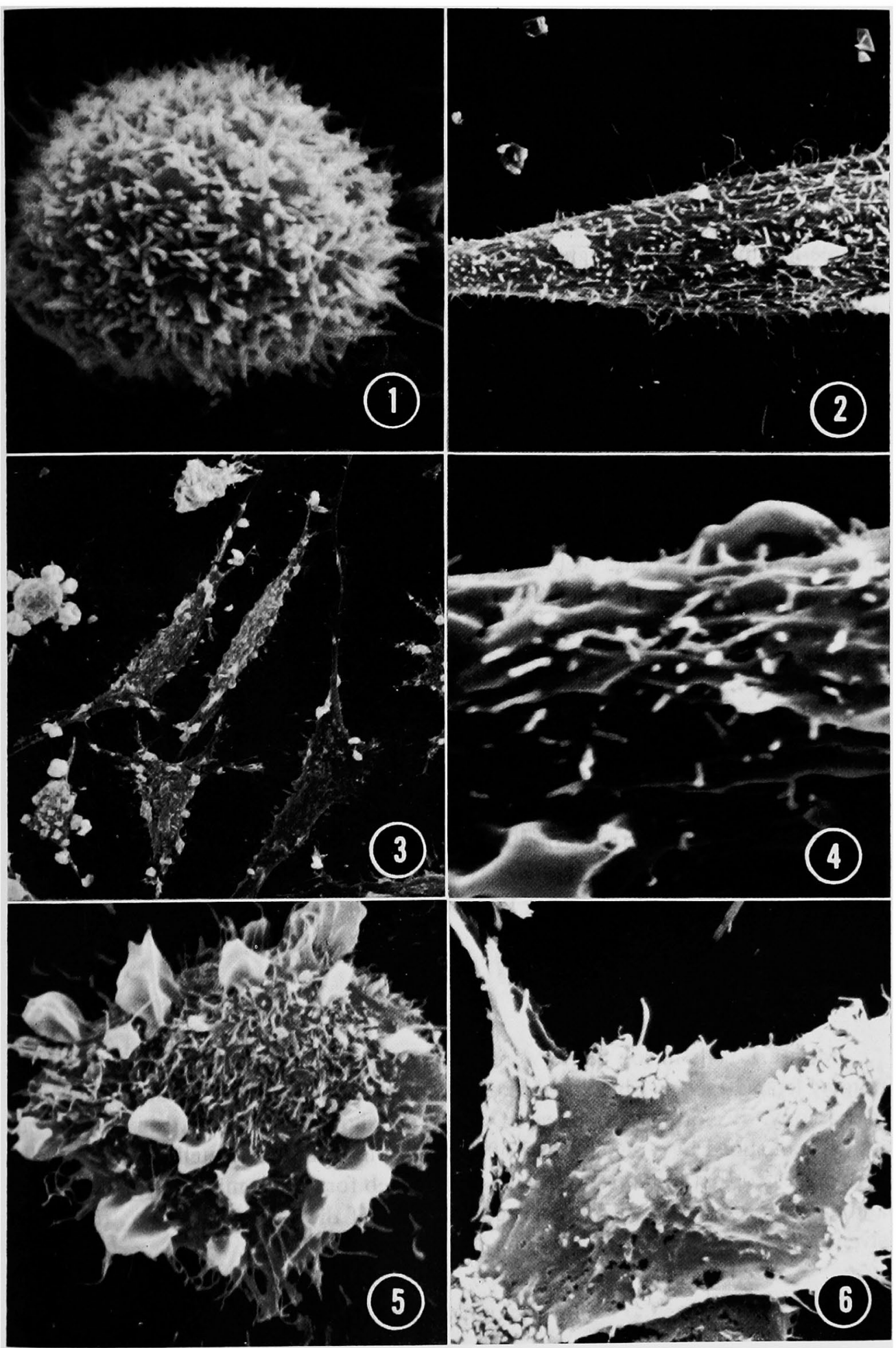




\section{Discussion}

Everhart and Rubin (1974), working with CB effects $(5 \mu \mathrm{g} / \mathrm{ml}$ for $5 \mathrm{~min}$ or longer) on synchronized $\mathrm{CHO}$ cell populations showed that the disappearance of blebs and microvilli, and the cell body contraction were typical surface morphology changes. Godman et al. (1975) suggested that the effect of $\mathrm{CD}(0.2 \mu \mathrm{g} / \mathrm{ml}$ in combination with ${ }^{3} \mathrm{H}$-thymidine for $10 \mathrm{~min}$ ) was greatest in the $\mathrm{G}_{1}$ phase of the cell cycle, but declined when the cells moved into the $S$ phase. However, the difference became less distinct when higher drug concentrations were utilized. In one part of this experiment, we applied a high level $(10 \mu \mathrm{g} / \mathrm{ml})$ of CB for a very short pulse $(20 \mathrm{sec})$ in which the formation of zeiotic blebs appeared throughout the population. The blebs were more obvious in rounded cells. In spindle shaped and stellate cells, there was a disappearance of microvilli and cell surface folding. In a CB dose level that suddenly caused an increased intracellular pressure and occurrence of gaps in the cortex, the level of an intracellular factor which could stabilize the surface membrane would not play a significant role. Johnson et al. (1972) postulated such a factor as being cylic AMP. We suggest the possibility that in individual cells the amount of pre-existing membrane per unit area might be a key factor in determining the extensiveness of zeiotic bleb formation. More villated morphology in rounded L-cells and some other cell lines (Knutton et al. 1975) apparently have a higher ratio of membrane per unit area than flattened cells because of the large numbers of microvilli (Figs. 1 and 2). Upon an increase in intracellular pressure, the availability of membrane material is essential for zeiotic bleb formation. Microvilli appear to be an available source which can supply membrane material to cover the zeiotic protrusions. Thus, rounded cells have a better possibility to form the zeiotic blebs than spindle shaped ones from the same cell line. The common surface folding of spindle shaped cells might be caused by unevenly distributed intracellular pressure. The route for redistribution of blebs observed in this study is similar to that previously shown for the same cell line in the capping of Conconavalin A binding sites (Weller 1974). This further suggests a common pattern for surface membrane movement.

\section{Summary}

Mouse L-cells in log phase were treated with cytochalasin B for time periods ranging from $20 \mathrm{sec}$ to $1 \mathrm{~h}$ and subsequently examined by means of scanning electron microscopy. Zeiotic blebs appeared within the shortest time period in all cells but was accompanied by a general loss of microvilli in spindle and stellate shaped cells. It is suggested that initial responses in zeiotic bleb formation may be dictated by the amount of pre-existing membrane per unit area of the cell surface, i. e., the extensiveness of microvilli.

\section{Acknowledgment}

This investigation supported in part by grants from the Faculty Awards Program of Bowling Green State University. 


\section{References}

Carter, S. G. 1967. Effect of cytochalasin on mammalian cells. Nature 213: 261-264.

Copeland, M. 1974. The cellular response to cytochalasin B. A critical overview. Cytologia 39: 709-727.

Everhart, L. P., Jr., and Rubin, R. W. 1974. Cyclic changes in the cell surface II. The effect of cytochalasin $\mathrm{B}$ on the surface morphology of synchronized Chinese hamster ovary cells. J. Cell Biol. 60: 442-447.

Forer, A. and Behnke, O. 1972. Cytochalasin B: Does it affect actin-like filaments? Science 175: $774-776$.

Gail, M. H. and Boone, C. W. 1971. Cytochalasin effects on BALB/3T3 fibroblasts: Dose dependent, reversible alternation of motility and cytoplasmic cleavage. Exp. Cell Res. 68: 226-228.

Godman, G. C., Miranda, A. F., Deitch, A. D. and Tanenbaum, S. W. 1975. Action of cytochalasin D on cells of established lines III. Zeiosis and movement at the cell surface. J. Cell Biol. 64: 644-667.

Johnson, G. S., Morgan, W. D. and Pastan, I. 1972. Regulation of cell motility by cyclic AMP. Nature (Lond.) 235: 54-56.

Knutton, S., Summer, M. C. B. and Pasternak, C. A. 1975. Role of a microvilli in surface changes of synchronized P815Y mastocytoma cells. J. Cell Biol. 66: 568-576.

Miranda, A. F., Godman, G. C., Deitch, A. D. and Tanenbaum, S. W. 1974a. Action of cytochalasin D on cells of established lines I. Early events. J. Cell Biol. 61: 481-500.

-, Godman, G. C. and Tanenbaum, S. W. 1974b. Action of cytochalasin D on cells of established lines II. Cortex and microfilaments. J. Cell Biol. 62: 406-423.

Porter, K., Prescott, D. and Frye, J. 1973. Changes in surface morphology of Chinese hamster overy cells during the cell cycle. J. Cell Biol. 57: 815-836.

Spudich, J. A. and Lin, S. 1972. Cytochalasin B, its interaction with actin and actomyosin from muscle. Proc. Nat. Acad. Sci. 69: 442-446.

Weller, N. K. 1974. Visualization of concanavalin A binding sites with scanning electron microscopy. J. Cell Biol. 63: 669-707.

Wessells, N. K., Spooner, B. S., Ash, J. F., Bradley, M. O., Luduena, M. A., Taylor, E. L., Wrenn, J. T. and Yamada, K. M. 1971. Microfilaments in cellular and developmental processes. Science 171 : 135-143.

Zigmond, S. H. and Hirsch, J. G. 1972. Effect of cytochalasin B on polymorphonuclear leucocyte locomotion, phagocytosis and glycolysis. Exp. Cell Res. 73: 383-393. 